\title{
Rethinking the 'debate on environmental refugees': from 'maximilists and minimalists' to 'proponents and critics'
}

\author{
James Morrissey $^{1}$ \\ University of Oxford, UK
}

\section{Introduction}

Writings on the relationship between environmental change and human migration often use, as their starting point, reference to the literature on 'environmental refugees' (Suhrke 1994; Castles 2002; Goffman 2006; McNamara 2007; Perch-Nielsen et al. 2008; Laczko 2009; Morrissey 2009; Gill 2010; Panda 2010; Bohra-Mishra and Massey 2011; Gemmene 2011). In the context of the increasingly urgent political debate around environment and migration/asylum, research has sought to discover whether or not environmental change or stressors can cause, or force, human migration. It is common to identify a 'debate on environmental refugees', in which two schools of thought are highlighted. In one, the link between environmental change and migration is thought to be simple and linear, while in the other it is thought to be messy and complicated.

This article seeks to achieve two things. The first is to critique the dominant presentation of the literature on 'environmental refugees'. There appears to be conceptual agreement, but with disagreement on how the environment-migration relationship is represented - specifically the term 'environmental refugee'. The article argues for a description of the literature on environmental refugees that is characterized in terms of 'proponents' and 'critics' of the 'environmental refugee' concept.

I then provide a nuanced critique of the 'proponent' position - a view which argues for the notional relevance of the 'environmental refugee' as a means for describing a person whose decision to move is based, in part, on the experience of environmental stress. The intention in doing so is to provide a context from which a more appropriately focused research agenda might be generated. In this regard the article highlights the apolitical, ahistorical and teleological nature of 'proponent' accounts. It therefore advocates further research, to focus on the historically relevant and contextually specific interactions between environmental and non-environmental factors that impact on mobility decisions undertaken in contexts of environmental stress. In order to achieve this, the article begins with an account of how the literature on environmental refugees and the relationship between environmental change and migration has evolved.

\section{2. 'Environmental refugees': a cause for concern}

The term 'environmental refugee' is often credited to Essam El-Hinnawi's United Nations Environment Programme (UNEP) paper (1985). Although it is often seen as an emergent issue given the contemporary concern about climate change, the term's initial use may be as early as the 1970s when it was first invoked by Lester Brown, the founder of the World Watch Institute (Saunders 2000). Nonetheless, it is generally accepted that the El-Hinnawi paper brought the term into public debate (Jacobson 1988).

The paper's effectiveness in raising the profile of the 'environmental refugee' was that El-Hinnawi provided the first formal definition of the term. This was important for operationalizing it, which in turn allowed for a blossoming of work that focused on both documenting the existence of migration forced by environmental crises, and on formulating numerical projections of future 'environmental refugees'. Important amongst these was a working paper by Jacobson (1988), notable for offering the first estimate of the number of existing 'environmental refugees' and suggesting the potential role that climate change might play in displacing people in the future. Jacobson's estimate of 10 million existing 'environmental refugees' - based on an assessment of the number of people displaced by the drought(s) in the African Sahel in the 1980s - was, in turn, important for lending legitimacy to the notion, allowing the media, charities and even other academics to refer to 'environmental refugees' as an existing rather than hypothetical category (e.g. Westing 1992, Islam 1992 and Otunnu 1992). In addition, Jacobson's recognition of the potential role of climate change in human displacement was a harbinger to what would become the dominant concern in writing and thinking on 'environmental refugees' during the first decade of the $21^{\text {st }}$ century.

An increased awareness of 'environmental refugees' was visible in a growth of literature linking environmental crises with human displacement throughout the early 1990s. Much of the writing on the topic introduced neo-Malthusian concerns, linking population growth with social and economic crisis, and with outmigration (Westing 1994; Westing 1992; Islam 1992; Otunnu 1992; Trolldalen et al. 1992). Evidence of the neo-Malthusian inclinations of these authors is their repeated reference to the notion of 'carrying capacities', with Westing (1992) going so far as to state that the appropriate conception of the 'environmental refugee'

\footnotetext{
1 Dr. James Morrissey is a Research Officer at the Refugee Studies Centre, Department of International Development, University of Oxford, 3 Mansfield Road, Oxford OX1 3TB, UK. james.morrissey "at" qeh.co.uk. He would like to thank an anonymous reviewer for their comments on this paper and Simon Batterbury for his work editing this manuscript. He would also like to thank The Journal of Political Ecology for their efforts at keeping the journal open access. May the rest of the academic publishing industry follow suit.
} 
problem was to see it not so much as an issue of land shortage but rather one of population 'longage' (Westing 1992:206).

In the latter half of the 1990s global climate change entered public debate more and more, and neoMalthusian accounts increasingly mentioned it as an important driver of human mobility. But population growth remained a central concern with the notion of 'carrying capacities' persisting (Ramlogan 1996; O'Lear 1997). In fact population growth became even more central as authors began to identify 'hotspots' for 'environmental refugees' by overlaying predicted changes in the physical environment (forecast under climate change models) onto projections of population growth (Döös 1997; Myers 1993; Myers and Kent 1995; Myers 1997; Myers 2001). Particularly notable in the literature linking population growth, climate change and mass human displacement was that it lacked empirical evidence. The work of El-Hinnawi (1985), Jacobson (1988) and Myers (1993 \& 1995) are clearly foundational to the field. Work by authors such as Westing (1992), Islam (1992) and Otunnu (1992) simply invoked the concept, citing El-Hinnawi (1985), before uncritically referring to Jacobson's (1988) figure of 10 million existing 'environmental refugees'. Similarly authors such as Ramlogan (1996), Döös (1997) and O'Lear (1997) cited various works by Myers in justifying their use of the concept

Myers' direct contribution to the literature spans the period 1989 to 2005 . His work is notable for citing massive numbers of both present and future 'environmental refugees', scaling up Jacobson's (1988) figure to twenty-five million people. This is greater than the number of 'convention refugees' recognized at the time ${ }^{2}-$ and he placed future estimates as high as 200 million by the year 2050 (Myers 1993; Myers and Kent 1995; Myers 1997; Myers 2001; Myers 2005).

Myers' contribution to the literature is notable because it is brought the 'environmental refugee' to prominence, and because he is the most prolific author in this genre. In addition, he sat on the editorial board of the academic journal Environmental Conservation which published both of Westing's articles $(1992,1994)$ as well as Ramlogan's (1996) paper. His conception of the 'environmental refugee' has become fundamentally important in shaping how the term has been taken up amongst academics, policy makers and the public.

For Myers, like other authors from the 1990s, such large numbers of 'environmental refugees' are hypothesized to result from the combined impacts of population growth and climate change (Myers and Kent 1995). For them, migration is the outcome of diminished agricultural production, reduced water availability and damage to physical infrastructure. Myers' sizeable predictions of 'environmental refugees' are bolstered by his view that population growth, which is not only responsible for degrading the environment, but also for leaving more people residing in drylands and low-lying areas, renders people vulnerable to climate change and more sensitive to pressure on resources (Myers and Kent 1995).

\section{Responding to the alarm: critical work on 'environmental refugees'}

Critical work on the topic extends as far back as the early 1990s. Early critics tended to be migration theorists who found that their experiences studying migration conflicted with, or were not entirely captured by, the characterization of human movements as driven by changes in the physical environment. They were critical of a number of elements of the 'environmental refugee' hypothesis.

Bilsborrow (1992) criticized the term 'environmental refugee' for the manner in which it afforded primacy to changes in the physical environment in decisions about human migration. This, she argues, overlooks the potentially important role played by other factors in the process. McGregor (1992) argued that the term denies the migrant any agency, or any ability to endure or adapt to changes in their physical environment. In a similar fashion Suhrke (1992) criticized El-Hinnawi (1985) and others for characterizing all forms of movement as refugee-like (despite differentiating them in terms of spatial and temporal extent). As such she argues that the notion of an 'environmental refugee' undermines the legal terminology 'refugee' as defined in the 1951 UN Convention. ${ }^{3}$

Despite the importance of these criticisms - which influence debates that continue today- it should be noted that none of the authors mentioned above claim the outright irrelevance of the 'environmental refugee' concept. At issue for them was the assumed relationships between a changing physical environment and the manner in which individuals make decisions about their patterns of mobility. In this regard the initial critics were not opposed to the existence of the term. Rather they were opposed its application to such a broad set of migrants responding to such a wide-ranging set of events. Bilsborrow (1992) suggests that the term 'environmental refugee' should not be scrapped entirely, but rather that it be used discerningly to describe only those migrants fleeing rapid and/or drastic changes in the physical environment.

Suhrke (1994) identifies two schools of thought on 'environmental refugees'. The first she describes as 'maximilist', and among whom she places authors such as El-Hinnawi (1985) and Jacobsen (1988). These authors, she claims, describe large numbers of existing 'environmental refugees' and predict greater numbers

\footnotetext{
2 'Convention refugees' refers to those individuals currently being provided asylum as a result of signatory countries obligations under the 1951 United Nations Convention on Refugees and the 1967 protocols.

3 The 1951 United Nations Convention Relating to the Status of Refugees.
} 
in the future. Surhke (1993 \& 1994) claims they tend to conceive of the link between changes in the physical environment and human migration as simply causative and direct. As such they predict large scale human migrations as a necessary outcome of large-scale changes in the physical environment.

Suhrke contrasts this 'maximilist' account with, what she terms, the 'minimalists', and among whom she includes authors such as Bilsborrow (1992) and McGregor (1994) who, she claims, emphasize the complexity of the interaction between environmental and social systems, and thus question the assumption of a direct causal link between environmental change and migration (Suhrke 1993, 1994). While it should be noted that Suhrke locates herself amongst the minimalists, what is probably more important in her work is the degree to which her characterization of the 'minimalist' and 'maximilist' perspective shaped how the literature on environmental change and human migration would evolve for the next fifteen years.

\section{4. 'Environmental refugees': a polarizing issue}

In the debate described above, there were calls for the term 'environmental refugee' had to be deployed in a more discerning manner. Effort was therefore spent by 'minimalist' scholars to provide a more appropriate conception of the 'environmental refugee'. In this regard authors sought to sub-categorize migrants responding to environmental stimuli (Bilsborrow 1992; Suhrke 1994).

Initial attempts at a more appropriate conceptualization of the 'environmental refugee' tried to distinguish whether they were responding to rapid- or slow-onset events (Suhrke 1993; Bates 2002), and how to discern 'environmental refugees', who flee environmental catastrophe, from 'migrants who move voluntarily in a context of environmental stress (Suhrke 1993; Hugo 1996). Others developed a continuum, classifying migrants in terms of the urgency of their need to move, and differentiating them based on the nature of the environmental disruption causing their movement (Hugo 1996; Bates 2002).

By the late 1990s despite objections from the 'minimalist' school and their alternative formulations, and a lack of empirical evidence to support 'maximilist' claims; writing on the 'environmental refugee' continued to grow and the alarming predictions of authors like Myers gained increasing traction amongst the general public (Ramlogan 1996; Döös 1997; O'Lear 1997; Myers 1997). At the same time, increasingly radical critiques started to appear within the 'minimalist' school. Whereas Billsborrow (1992), McGregor (1994), Suhrke (1994) and Hugo (1996) had acknowledged the potential value of the 'environmental refugee', Lonergan (1998) denied its relevance entirely.

For Lonergan (1998) the problems of separating environmental processes from social, economic, political and institutional structures meant the adjectival prefix 'environment' was entirely invalid. As such any notion of an 'environmental refugee', 'environmental migrant' or 'environmentally displaced person' was nonsensical. Instead of focusing on environmental issues, he points out the significant role development plays in generating vulnerability to environmental change (Lonergan 1998). He argues that at the root of what often appears to be environmentally determined migration is actually the developmental disparities between the Global North and the Global South (Lonergan 1998). Lonergan (1998) also echoes the sentiments of Billsborrow (1992) and McGregor (1994) when he calls into question the manner in which 'maximilist' works have failed to account for the ability of populations, affected by environmental change, to adapt to that change in ways that mitigate the need to relocate (Lonergan 1998).

Although Lonergan (1998) rejected the sensibility of the term, the clearest, outright rejection of the entire concept comes from the writings of Richard Black (1998, 2001). Black's argument (provocatively titled Environmental refugees: myth or reality? 2001) is the most drastic attempt at debunking the environmental refugee thesis altogether. Taking specific aim at the works of Myers, Black makes use of three attacks on the 'maximilist' conception. Firstly he undermines the 'maximilist' descriptions of environmental crisis, focusing on works which call into question the processes of desertification in particular (described in numerous 'maximilist' works). Secondly he elaborates Suhrke's (1992) critique, arguing that the 'refugee' label does not fit all migrants responding to environmental change. He points to evidence that indicates vegetative cover has historically rebounded from cyclical droughts in the Sahel and also argues that migration among nomadic Sahelian herders is a fundamental part of Sahelian livelihoods, not an exceptional refugee-like movement. Thirdly, in addressing sea-level rise as a cause of environmental refugees, Black (2001) echoes Lonergan's (1998) sentiments, calling into question the primacy of environmental change as the driver of migration. Here he argues that it is poorly planned development and global North-South disparities that are largely to blame for generating vulnerability to hazards such as flooding. Thus, for Black, environmental change is, if anything, only a proximate cause of displacement while the root of the problem lies in global developmental inequalities (Black 2001).

In summary, while some authors predict hundreds of millions of environmental refugees to accompany climate change, others deny the existence of the category altogether. Other summaries of these debates have been made since the early 2000s. With anthropogenic climate change becoming an increasing global concern, the debate has become further polarized, although more in public fora than in academic discussion (Conisbee and Simms 2003; Christian Aid 2007; Rajan 2008). Advocates of action on global warming still invoke the possibility of hundreds of millions of environmental refugees, in order to confront the public with the consequences of continued inaction on GHG emissions (Christian Aid 2007; Rajan 2008; Campbell 2008). 
On the other side of the debate, national governments have not acted on the possibility of environmental refugees driven to move because of anthropogenic climate change. Concern existed that acknowledgement of the concept would be tantamount to accepting responsibility for the forced migration of large numbers of people (McNamara 2008). This in turn, it was feared, could be used as grounds to argue for compensation by industrialized countries for people's displacement in the Global South, which itself could set a precedent for compensating people for the impacts of climate change more generally (McNamara 2008).

As the context of anthropogenic climate change has raised the stakes in the public debate over the existence of 'environmental refugees', empirical work on the topic has began to emerge. But the issue has been redefined - the question of "whether or not 'environmental refugees' exist", has come to be interpreted as "whether or not environmental change can cause (or worse, force) human migration".

Several high-profile studies have set out to determine correlations between environmental degradation and human migration. Exemplary in this regard is research by Massey et al. (2007), and Feng et al. (2010). While coming to opposite conclusions, both sought to explore correlations between perceived environmental problems and human out-migration. The EU funded EACH-FOR project tests a research hypothesis that "There is a discernible environmental signal in human migration patterns today" (Warner et al. 2011:192). The means for testing were two-fold. They were to (i) "investigate correlations between migration and environmental degradation" and (ii) "produce a series of case studies investigating the correlation between environmental degradation and migration patterns" (EACH-FOR 2009). While the study claimed to find evidence of meaningful linkages between environmental change and human migration, it took heavy criticism for its research method, which, it was argued, biased results towards finding that environmental variables had played a role in mobility decisions (Personal communication: Warner 2009).

In addition to these studies, the degree to which debate in the literature came to be about whether or not environmental change plays a role in human migration is reflected in the changing way that the IPCC dealt with the issue of human migration in response to climate change. In this regard it is remarkable that the IPCC appeared initially, to focus on the work of El-Hinnawi (1985) and Jacobson (1988), warning that "the gravest effects of climate change may be those on human migration as millions are displaced by shoreline erosion, coastal flooding and severe drought" (IPCC 1990:20). Subsequent reports, however, reflect growing criticism of the term, changing their tone and moving away from alarming accounts by focusing instead on the complexity of the processes described in the literature on 'environmental refugees', as well as on issues of human vulnerability (Raleigh et al. 2008). By 2001, the IPCC Report came to reflect the view of the 'minimalist' school, eliminating any reference to human migration as a consequence of climate change (Raleigh et al. 2008; Watson and Albritton 2001). Such a shift suggests that the question about the existence of 'environmental refugees' had been resolved by a view which presumed environmental change to have no impact on human mobility.

Academic literature and policy studies on the relationship between environmental change and human migration appears to have been heavily influenced by writing on 'environmental refugees'. A close reading suggests that instead of a clear debate occurring about the importance of environmental factors in mobility decisions there is, in fact, a great deal of consonance between the 'maximilist' and 'minimalist' authors. For when reading the work advocating either position one cannot help but be struck by the conceptual concessions made by scholars in both camps. Despite common references to the 'debate on environmental refugees', it is quite possible to read work on 'environmental refugees' and identify significant portions of conceptual overlap (Castles 2002; Stavropoulou 2008; Morrissey 2009; Gill 2010).

\section{Consonance in approach: agreement on 'environmental refugees'}

From the literature on environmental refugees one can identify three major critiques of the 'maximilist' position. The first is that it problematically labels all migrants as 'refugees', when in fact there are important distinctions. The second is that it wrongly assumes that the natural environment is easily distinguishable from the social, political and economic context in which it coexists; and the third is that empirical evidence on migration in response to environmental stress shows it to be dominated by short distance, temporary and cyclical movements. Environmentally induced migration is not, as the maximilists suggest, long distance and permanent (Findlay and Geddes 2011). This next section seeks to challenge these characterizations of the 'maximilist' account, citing instances where such features are acknowledged by authors writing from the 'maximilist' position.

When advocating for the acknowledgement of 'environmental refugees' as an indicator of Bangladesh's developmental problems, Islam (1992) argues that there is a difference between individuals migrating in search of a better life and migrants having to leave an area for fear of dying as a result of environmental destruction. The former he describes as 'migrants' while the latter, he claims, are effectively conceived of as 'refugees'. Similarly, Ramlogan (1996), another 'maximilist', argues that at the heart of the issue of who is an

\footnotetext{
${ }^{4}$ The details of this issue lay in the format of the semi-structured questionnaire, which actively enquired about the role of the environment in mobility decisions. Such an approach was criticised for privileging answers which made reference to the role of the physical environment in mobility decisions.
} 
'environmental refugee', lies the decision-making process of the migrant. It is here that it is possible to distinguish whether that migrant is 'forced' or 'voluntary' and thus whether the title 'environmental refugee' is appropriate. Notably these conceptions echo the sentiments of 'minimalist' scholars, such as Suhrke (1994) and Hugo (1996), who separate 'migrants' from 'refugees' by distinguishing between forced and voluntary migrations, which they see as determined by the nature of environmental change.

Otunnu (1992), while advocating for the legitimacy of the term 'environmental refugee' and at the same time forecasting large numbers for the future, states:

Various factors ... directly or indirectly lead to environmental deterioration... It should be indicated straightaway that there are no impenetrable walls between environmental, political and economic factors - they are, at one and the same time, causes and effects of environmental crisis. (Otunnu 1992:11)

In addition, Otunnu blames the conditions generating 'environmental refugees', in sub-Saharan Africa on "the nature of the state, the political economy of sub-Saharan Africa, and the international economic system" (Otunnu 1992:11). Similarly, Islam (1992) places 'environmental refugees' on the continuum of economic refugees and then blames (what he views as) the impending environmental refugee crisis, in Bangladesh, on the laws of peripheral capitalism and the nature of the aid industry.

Even Westing (1992) and Myers (1993, 1995, 1997 \& 2001) in their strong 'maximilist' arguments at least acknowledge the importance of the political context when saying that the problems of environmental refugees will be worst in developing countries because they are both "ill-equipped to deal with ... threats to their sustainable development" (Westing 1992:205) and because the "costs of [adaptation] measures are likely to prove too high for many [of them]" (Myers 1993:753). Ramlogan (1996) and Döös (1997) similarly account for multiple drivers of migration in their descriptions of 'environmental refugees', with Ramlogan stressing poverty as an important component of migration in the Sahel and Döös (1997) citing wars, religious intolerance unemployment, poverty and wage differentials as important factors.

Finally, despite it forming a fundamental feature of 'minimalist' critiques, 'maximilist' scholars openly acknowledge that migrations made in response to environmental change may well occur over short distances. In this regard, Ramlogan (1996) acknowledges that environmental change will generate both internal and international migrants, while Myers (1993) is explicit about the complications of defining 'migration' in terms of geography:

And if they do move what constitutes true migration? Some people ... may need to move their place of residence only a short distance; [for example] certain coastal communities may find that residents need simply move across town. (Myers 1993:757)

It seems that the criticisms leveled at the at the 'maximilist' position are misplaced. Their account of environmental refugees has not described them as all moving long distances and being permanent migrants, it has not homogenized all migrants as refugees and it has acknowledged the porous boundaries between the conceptual constructions of society, politics, economics and environment. Notably authors in the 'maximilist' camp complain that critiques of them have misrepresented their position (Personal Communication: Myers 2008).

On the other side of the debate, it has already been mentioned that a number of 'minimalist' authors, wary of the problematic use of the term 'environmental refugee', have been careful not to deny its legitimacy altogether (Bilsborrow 1992; Bates 2002; Hugo 1996; McGregor 1994). Likewise, Lonergan (1998), in his critique of the term notes that environmental factors could play an important role in decisions about human mobility and that we simply don't yet understand these processes sufficiently well. Even Black (2001) states that he is not arguing that changes in the physical environment do not play an important role in migration decisions. This is evident in his work, which focuses on circular migration in response to periodic drought in the African Sahel, thereby implicitly acknowledging that rainfall distribution can play a role in mobility decisions (Black 2001). So while maximilists appear to acknowledge the complexity of the processes linking environmental change to mobility, there appears to be general agreement, amongst 'minimalist' authors that features in the bio-physical environment may play some role in shaping mobility decisions.

There appears, therefore, to be a problematization of the relationship between environmental change and human migration in different camps, even though there is quite clearly significant debate over 'environmental refugees'. We are presented with something of a paradox, since there appears to be a highly polarized debate over a subject matter about which there is a large amount of agreement. Disagreement pertains to the use of the term 'environmental refugee' and not to the link between environmental change and human migration. I argue that the 'debate on environmental refugees' is really a debate about how a relationship is represented, and less about the nature of the relationship itself.

The following section of this article is focused on exploring the representational elements of the 'environmental refugee' with the intention of understanding why particular representations might prove 
contentious. I explore the conceptual origins of the 'environmental refugee', looking at the relationships between the term's institutional origins and the development narratives, and subsequent policy responses, which it prescribes.

\section{The 'environmental refugee': an evolving concept}

The term 'environmental refugee' has conceptual roots reaching as far back as the 1930s (Saunders 2000). Evidence of linkages between neo-Malthusian concerns and outmigration go as far back as Dennery (1931), who warns of the implications of 'overpopulation' on the Indian sub-continent and outmigration as a result. A more concrete reference to the term appears later in Vogt (1949) who described 'ecologically displaced persons' when writing on migrants leaving the north American prairies during the dust-bowl years of the 1930s (Saunders 2000).

What is most notable about these early works is the degree to which they highlight long-standing development narratives which persist in writing on the topic into the 1990s (Adger et al. 2001). While neoMalthusian logic and a concern over drylands and desertification in the literature on 'environmental refugees' is pervasive and long-standing, so too is a politics aimed at environmental protection and conservation. Notable in this regard is the role of the World Watch Institute, whose founder, Lester Brown, coined the term and who also published Jacobson's (1988) seminal piece; and UNEP, who published El-Hinnawi's (1985) paper. Westing (1992) says the latter was written with the explicit intention of garnering support for addressing environmental problems. It seems that the notion of the environmental refugee was used to achieve environmental conservation/protection outcomes, particularly in drylands (a trend that I will show continues to this day). It is worth briefly exploring precisely how this occurred.

The argument for environmental protection appears to be reliant on two features in the 'maximilist' literature. The first is to cast human mobility as a problem. The second is to present this problem as occurring on a scale which makes palliative measures at addressing it seem impossible. Regarding human mobility as a problem, two senses of the word are relevant. The first stems from the environmentalism of the 1970s that was popularly informed by notions of balance and equilibrium (Robbins 2004; Forsyth 2003). The existence of 'environmental refugees' was used to suggest that significant changes in the physical environment were taking place. Since such change was conceived as a shift away from some idealized, climax equilibrium, it was thought to be inherently problematic and as such the 'environmental refugee' became emblematic of an environmental problem.

The second sense in which the 'maximilist' literature casts 'environmental refugees' as a problem pertains to their representation as a social problem. This is achieved in two ways. The first focuses on the vulnerability of migrants, presenting 'environmental refugees' as an humanitarian problem (Islam 1992; Otunnu 1992; Myers 1993); while the second focuses on security and stability, casting environmental refugees as problematic in receiving areas (Westing 1994; Ramlogan 1996; O'Lear 1997; Myers and Kent 1995). Notable in this second sense of environmental-refugees-as-a-problem, is the manner in which it draws on the paradoxical nature of the 'refugee' as, at one and the same time: hapless victim and resourceful agent. The former being acutely vulnerable and incapable of responding to changes in the social context or physical environment, while the latter is capable of destabilizing entire nation states.

We therefore have the 'environmental refugee' cast as both an environmental and a social problem, as well as being both the result of a problem and a problem in and of itself. The second argument in favor of environmental protection is to present the 'environmental refugee problem' as occurring on a scale which would make it impossible to address in any palliative fashion. Proponents of the 'environmental refugee' focus on the impossibility of absorbing migrants, or on the great suffering such migrants would undergo during their movement. Since one cannot safely absorb the migrants or mitigate their suffering, policy prescriptions aimed at addressing the cause of the problem - environmental degradation - are presented as the only rational action. Stop them needing to migrate.

Drawing upon the paradoxical notion of the refugee (as both victim and agent) is important in understanding the effectiveness of 'maximilist' accounts in advocating for environmental protection. On the one hand, the security narrative, which transfers the costs of environmental problems in one place to another through the movement of people, provides an individualist motivation for implementing policies aimed at addressing 'environmental problems'. On the other hand, the vulnerability narrative generates a humanitarian imperative by which it is similarly rational to undertake measures that will address 'environmental problems' lying at the core of people's vulnerability. Thus 'maximilist' accounts are particularly effective because, by drawing on the paradoxical notion of the refugee, they can generate allegiances across the political spectrum, thus uniting groups that are usually at odds, particularly on issues pertaining to immigration and the environment.

Given this neo-Malthusian conceptualization, it should come as no surprise that not only were the seminal articles on the topic written by environmentalists, but that such writings occurred during high points of support for environmentalism. It was in the 1970s that Lester Brown first breathed life into the term, accompanying the first wave of environmentalism (Young 1990; McNamara and Gibson 2009). Similarly, it was with the second wave of contemporary environmentalism in the late 1980s and early 1990s that the term 
was reinvigorated through the writings of El-Hinnawi (1985). Jacobson's piece (1988), which warned of the potential for climate change to drive future human migrations, was published in the same year as the IPCC was established, and Myers and Kent (1995) was commissioned by the Climate Institute (a Washington-based NGO) with the expressed intention of raising the profile of climate change issues (McNamara and Gibson 2009).

It appears that the notion of an environmental refugee has been deployed as a means to garner support for environmental protection for some time. Although this analysis is revealing, it does not present an explanation as to why there has been such a forceful dismissal of the term 'environmental refugee'. One might well ask "What's wrong with trying to protect the environment?" To answer this question, I turn to a brief exploration of the changing political context around issues of asylum and migration, in which the portrayal of asylum seekers and migrants as problems has been an issue of long-standing concern.

\section{Resolving the paradox}

If we are to understand the polarization of the literature on 'environmental refugees', we require a similar understanding of the changing politics of migration and asylum, during the latter half of the $20^{\text {th }}$ century.

During the early days of the Cold War, asylum seekers were welcomed by the West as emblematic of the moral and economic victory of liberal capitalism over state-lead socialism (Gibney 2004). The nature of these representations first changed in the 1970s when improved air travel and an escalation in Cold War shatter-belt conflicts in the Global South lead to a rise in the number of ethnically and racially distinct asylum seekers (Bosswick 2000). Such a change accompanied a shift in perception, and asylum seekers came to be identified as a security threat on the grounds of socialist subversion (Geddes 2003). With the collapse of socialism in the late 1980s, the instrumental value of the asylum seeker, as highlighting the superiority of liberal capitalism, was lost. In such a context the discourse on asylum seekers changed, magnifying the mistrust and animosity that had registered in the 1970s, so that the once pervasive descriptions of refugees as resourceful, bastions of capitalism morphed into a focus on lazy, dishonest welfare cheats, cast as a drag on the system (Gibney 2004; Joppke 1999).

Accompanying this change in perception was increased animosity towards generous asylum policies, attacked by a discourse focused on being 'swamped', 'flooded' or 'overwhelmed' by outsiders (Bosswick 2000). Within this context refugees have come to be seen as a problem, with the notion of 'bogus asylum seekers' becoming pervasive in public fora. From the late 1980s there has been increasing restrictions directed at the South-North movement of people.

While writing on 'environmental refugees' came to prominence during periods of popular environmentalism (McNamara and Gibson 2009), it also coincided with moments in which migrants and asylum seekers were increasingly being perceived as a problem. This makes sense given the degree to which the 'maximilist' narrative of 'environmental refugees' is reliant on the portrayal of refugees/migrants as problematic in order to rationalize policy aimed at environmental protection.

In this context the polarizing writing, Black (2001) makes sense. His objection to the term 'environmental refugee' does not lie with the notion of a link between environmental change/stress and human mobility, but rather with how the environmental politics of the 'environmental refugee' has the potential to undermine the protections currently afforded to refugees (as defined in the 1951 Convention) as well to as buttress growing anti-immigration sentiment (Black 2001). Black fears that the evocation of large numbers of 'environmental refugees' could allow states to shirk on their Convention-defined responsibilities to asylum seekers. The problem, he argues, is that the lack of reference to 'environment' in the 1951 Convention means that receiving states could, citing the huge numbers of 'environmental refugees' forecast to exist, reasonably claim that at least some of the asylum claimants they receive are fleeing environmental catastrophe, not political persecution. Since signatory states to the 1951 Convention have no obligation to address issues of environmentally motivated migration, they could refuse asylum to a multitude of asylum seekers on the grounds that addressing their plight falls outside of their Convention-defined responsibilities.

In addition to such concerns, the notion of an 'environmental refugee' has been rejected even where its use has been well-intentioned with regards to migrant protections. For where the term has been invoked as a means to call for amendments to the 1951 Convention - so that it include reference to issues of environment (See 2007) - migration scholars have opposed the term fearing the re-opening of negotiations on the definition of the 1951 Convention. Concern here pertains to the context of increasing restrictionsim towards asylum and migration (just described), in which it is feared that any opening for renegotiation might actually result in a more restrictive definition of who qualifies as a refugee, or result in existing signatories to the Convention withdrawing from it altogether (Cournil 2011).

Regarding the linkages between 'environmental refugees' and anti-immigrant or anti-asylum sentiment, concern is based on the manner in which 'maximilist' literature plays into the general notion of states being overwhelmed and/or overrun by immigrants. Explicit evidence of how such narratives might be manipulated is referred to by Lonergan (1998) as a 'greening of hate'. In a similar fashion, writing on the security threat posed by 'environmental refugees', plays into other long-standing anti-immigrant narratives that connect migrants with crime, violence and disease. 
What, then, does this tell us about the paradox in the literature on environmental refugees? The paradox becomes clearer if we see the debate in the literature as a discursive one about the legitimacy of the term 'environmental refugee', rather than a debate about the appropriate conception of the relationship between environmental change/stress and human mobility - a relationship about which there appears to be general agreement. For advocates of the 'environmental refugee', concern lies with generating a response to what are perceived as looming environmental crises and the subsequent human vulnerability such crises might entail. It does not lie with the details of how environmental change manifests in migration. In the case of those authors who reject the notion of an 'environmental refugee', the issue is not with the fact that there might be a link between environmental change and migration. Instead the issue lies in the discursive linkages which the term invokes, and which it is thought fuel anti-immigrant sentiment and are detrimental to the rights of asylum seekers. Thus authors on both sides of the 'debate' are capable of agreeing on the fact that environmental change could have a role to play in mobility decisions, they are willing to agree that other factors matter in these decisions, that mobility (as a strategy for dealing with environmental change) might generate varying degrees of duress and involve migrations of a variety of temporal and geographical extents. What they disagree on however is the degree to which such features (in)validate the usefulness of the term 'environmental refugee'.

I suggest a new language for describing the different positions on 'environmental refugees'. I would like to move away from Suhrke's (1994) 'maximilist' and 'minimalist' positions, based on the degree to which different authors conceptualize a simple, or complex, link between environmental change and human migration. Instead, because of my prioritization of the discursive debate over the conceptual one, I would like to suggest the terms 'proponents' and 'critics' of the 'environmental refugee'. This is because such a characterization allows for conceptual agreement, while highlighting the different degree to which authors (in spite of their agreement on conceptual issues) disagree about its relevance due to the discursive linkages it invokes.

\section{Providing a nuanced critique}

In showing how debate in the literature on environmental refugees has been poorly characterized in terms of causation, when really it was about representation, it should not be understood that this article is suggesting that the 'proponent position' is not without conceptual problems of its own. Rather, theoretical deficiencies are revealed in 'proponent' accounts. A critical reading of this position is valuable to reveal conceptual deficiencies and to generate a research agenda focused on questions able to improve our understanding of the relationship between environmental change/stress and human mobility.

It has already been pointed out that 'proponent' accounts have replaced neo-Malthusian narratives of environmental change with a greater focus on anthropogenic climate change. But neo-Malthusian logics have not been purged from 'proponent' accounts. Additionally, as Forsyth (2003) notes, narratives of environmental crisis have long been used as a means for raising awareness and gaining political will to support the precautionary principle in environmental politics. These narratives often generate simplistic conceptualizations of environmental problems. A close reading of 'proponent' accounts linking climate change to migration suggests that a great many neo-Malthusian and simplistic conceptualizations of environmentsociety relations persist, and are not accounted for in the resolution of the paradox described above. Specifically, the 'proponent' account is reliant on two problematic conceptualizations. The first pertains to a simplistic account of migration. The second is a neo-Malthusian-inspired conception of the developing world which is both ahistorical and de-politicized. ${ }^{5}$

\section{The simplistic account of migration}

Some elements of this problem are addressed in the critical literature described above. Some 'proponent' accounts fail to describe how environmental change generates migration, instead only offered a description of how particular environmental changes will generate household stress, assuming that migration will present as an inevitability from there (discussed in Castles 2002; Mortreux and Barnett 2008). Moderated 'proponent' accounts, such as Perch-Neilsen et al. (2008), defend this, arguing for the relevance of what they term 'common sense models' - 'common sense', referring to the assumption of migration as an inevitable outcome of vulnerability. Despite claims to such connections being 'commonsensical', they are problematized by three arguments from established migration theory. ${ }^{6}$

The first major problem with 'common sense' assumptions pertains to their reliance on simplistic push-pull models of migration and neo-classical conceptions of the migrant. Invoking the push-pull heuristic, 'proponent' models simply see increasing environmental stress as increasing the push factors out of rural areas.

\footnotetext{
${ }^{5}$ An exception to this is work by Otunnu (1992) and Islam (1992) who, while citing population growth as a root cause of social crisis in sub-Saharan Africa and Bangladesh respectively, also explicitly describe the role of aid, capitalism and colonialism in the generation of environmental crises.

${ }^{6}$ See Castles \& Miller (2009) and Massey (1993) for good reviews of established migration theory.
} 
By the neo-classical conception of the rational migrant, increasing push factors results in outmigration to areas that are less vulnerable. Here vulnerability has replaced wages so that, in 'proponent' accounts, migration occurs as the rational end point of vulnerability. The critique of such an approach is that it takes no account of how migration may be constrained (Massey et al. 1993, Castles \& Miller 2009) and fractionalizes the drivers of migration so that it pays no attention to the broader structural features that may be shaping both the manner in which 'push' factors operate and the existence of 'pull' factors in receiving areas (Zolberg et al. 1989). In addition, we are left guessing about the temporal and geographical extent of mobility strategies.

The second problem is a conception of society as normally sedentary, where migration represents a response to some disruption to the normal way of life. Such a view draws on a pervasive and long standing notion of migration, particularly in the less industrialized Global South, as indicative of a failure of 'development' (Bakewell 2007). This has had particular relevance in the climate change debate where migration has been suggested as an indicator of people's 'failure to adapt' (Findlay and Geddes 2011; Warner 2009). The problem with such an approach is that it makes migration exceptional, placing it at the locus of a social problem. Such a view fails to account for the fact that migration and mobility might be long-standing livelihood strategies, as ordinary a response to changing livelihood options as diversifying, or changing, one's income stream.

The third critique of the 'proponent' conception of migration is that it ignores its dynamic nature. This is a product of 'proponent' models taking a quantum view of time through their approach which simply overlays predicted environmental change onto predicted population distributions at a single point in the future. Such an approach fails to account for the dynamic nature of migration and the changing relationships generated by positive and negative feedbacks which operate through flows of information and remittances (Castles and Miller 2009). Such effects have been shown to have important impacts on subsequent mobility strategies, most notably through processes such as cumulative causation (Massey 1990). The omission of such features in 'proponent' accounts therefore presents a significant over-simplification of migration processes.

\section{The ahistorical and de-politicized conception of the developing world}

I pointed out that 'minimalist' critiques were overstated in their claim that the 'maximilist's had failed to acknowledge the importance of factors other than environmental change in decisions about human mobility. Even the most alarming accounts of Westing (1992) and Myers and Kent (1995) had acknowledged that the impacts of climate change would be worse in the developing world, and had tacitly acknowledged that context is important. The problem with 'proponent' narratives is not that they don't take account of context; rather it is that they assume a particular context in the developing world which, because of their modernist assumptions about the process of 'development', is both apolitical and ahistorcial.

An apolitical and ahistorical account is central to Neo-Malthusian explanations in general. This is because it is only from a vantage point of naturalized poverty and vulnerability (as the inevitable state of pre-industrial society) that population growth can be highlighted as the variable with the most predictive power. NeoMalthusian explanations generally fail to engage in analyses of internal differentiations in wealth and power within less industrialized societies, take no account of technological innovation in local production systems and seek no account of how historically specific, socio-political events have acted (and continue to act) in (re)producing poverty and structuring inequality.

'Proponent' accounts of the 'environmental refugee' still invoke modernist and teleological accounts of environment-society relationships in developing countries. They will frequently acknowledge the important role played by poverty in shaping vulnerability to climate-related stress, but then fail to provide any account (or suggest any understanding) of the historical and contemporary processes structuring both the production and reproduction of poverty. Instead poverty is simply explained away as the natural and inevitable state of a pre-industrial society. Similarly, no attention is given to society's ability to adapt and/or change - a critique which has been pointed out already in the critical literature.

Notably, such apolitical and ahistorical accounts are not only a conceptual failing of 'proponent' models but are in fact necessary for the production of their discursive legitimacy and particular development narrative. Ahistorical accounts are important because they simplify the link between environmental change and migration. This is because such accounts need not be obscured by references to antecedent socio-political events which structured contemporary and historical patterns of vulnerability, and which shape persisting structures that marginalize societies and their ability to build resilient social systems. This, in turn, allows the 'proponent' model to focus on environmental change as the principal driver of migration, which itself is a requirement for claiming that the best policy response is to address the perceived environmental problem.

In addition, ahistorical and apolitical accounts allow for vulnerability to be homogenized across large regions. For if economic development is the only process that matters in building resilience, then a lack of development generates equally vulnerable societies. This homogenization is important to 'proponent' accounts because it allows for the assumed relationship between poverty, climatic stress and migration to be applied across large geographic areas. This, in turn, allows large numbers of migrants/refugees to be forecast and rules out the palliative policy option, making instead a case for addressing the perceived environmental problem. 
Thus, while a focus on the discursive implications of the term 'environmental/climate refugee' is meaningful for explaining the increasingly polarized nature of a literature in which there is actually a great deal of conceptual agreement, certain conceptual problems persist within the 'proponent' account. A number of these have been highlighted in the literature which critiques the simplistic view of migration (Castles 2002; Mortreux and Barnett 2008; Tacoli 2009) and the failure to account for other features that might affect mobility (Bilsborrow 1992; McGregor 1994). From the more nuanced critique offered here it seems that at the root of these problems is the 'proponent' accounts' particular sedentary bias and their teleological, modernist view of development. The latter has generated an ahistorical and apolitical view of the Global South.

\section{Conclusions and thoughts on future research}

What conclusions can we draw from the literature on environmental refugees and the critique of the 'proponent' position?

The insights provided by this article stem from the identification of the 'proponent' and 'critical' positions on environmental refugees, and their distinction from 'maximilist' and 'minimalist' accounts. In identifying such a subtle distinction, I show that the issue is not that 'proponent' accounts argue against the relevance of non-environmental factors. Rather the issue is that assumptions within the 'proponent' model discount the contextual specifics of historical processes in countries containing communities that are vulnerable to environmental change.

There is virtually no debate about whether environmental change, or stress, impacts on decisions about human mobility. Such a position is accepted, even by the fiercest critics of the notion of an 'environmental refugee'. Studies should shift their focus to explore the more interesting question - the relationship between environmental and non-environmental variables in shaping mobility imperatives and decisions, in communities experiencing environmental stress.

This has been explored in the EACH-FOR project (mentioned above) which, in addition to seeking out correlations, also focused on "discover[ing] and describ[ing] the causes of forced migration in relation to environmental degradation/change and their association with other social, political and economic phenomena ..." (EACH-FOR 2009). ${ }^{7}$ The evidence for anthropogenic climate change has further shifted the debate away from neo-Malthusian concerns (Wigley 2005). More complex linkages between environmental stress and the decision to move are viewed as important (Gill 2010; Mortreux and Barnett 2008; Tacoli 2009). And yet some recent research still focuses on the argument against using the term 'environmental refugees' based on the fact that migrations are short in distance (Gill 2010; Tacoli 2009; Massey et al. 2007) and are temporary (Raleigh et al. 2008; Gill 2010). I have shown that this is, in fact, admitted by 'proponent' authors.

The interaction between environmental and non-environmental factors should be examined in a way that is contextually specific and historically relevant. Research would be suspicious of the idea that singular nonenvironmental factors might act in a uniform manner in different contexts. For example, it seems specious to suggest that the relationship between environmental stress and mobility will be invariant, despite the existence of other important variables like existing social conflicts.

A contextual and historical approach queries issues of power, asking why particular relationships matter and how they came to be. For example when the findings of the EACH-FOR project state that 'land tenure matters' (EACH-FOR 2008:5), the question must surely be asked, how does it matter (what are the mechanisms by which access to land affects mobility in a context of environmental stress) and why do tenure relationships operate the way that they do? Further research would explore the mechanisms by which environmental stress translates into mobility (rather than simply assuming a connection between livelihood insecurity and outmigration as 'proponent' works have done (Castles 2002; Tacoli 2009). It would highlight the rich contextual and contingent nature of these relationships, which lie at the heart of understanding mobility decisions in a context of environmental stress. It will highlight a host of other, non-migratory, livelihood responses (e.g. reducing the number of meals taken, selling household assets, mobilizing political will for assistance, etc.) that may also manifest as responses to environmental stress, and thus shape human wellbeing. By questioning the historical processes that structure the non-environmental features vital in shaping mobility in a context of environmental stress, an historical approach would serve to problematize our understanding of causation.

An exploration of important non-environmental factors will identify a range of factors linking the global North with impacts in the global South. For example, agricultural policies are a feature of the global political economy, and have important historical effects on access and livelihood. So too will patterns of land tenure, regional conflict, aid policies, etc. (Robbins 2004). A complete understanding of the forces structuring mobility decisions requires an acknowledgement of the historical embeddedness of other non-environmental

\footnotetext{
7 Similarly, acknowledgement of the important role played by non-environmental factors is apparent in the study by Feng et al. (2010) (also mentioned above) that notes that its findings should not be extrapolated to contexts other than Mexico, due to the particular nature of Mexico's proximity and relationship with the United States. Indeed a critique of the predictions offered by Feng et al. (2010) is that they rely on certeris paribus assumptions for the host of nonenvironmental factors which might impact on mobility decisions in other contexts.
} 
factors which also shape mobility decisions.

There are likely to be important interactions both between livelihood strategies not involving mobility and those which do, as well as between those individuals who choose to migrate and those who do not. Such interactions, as well as the implications of mobility (in a context of environmental stress) for the sending and receiving areas, are dynamic elements of the mobility response which need to be understood if we are to generate a comprehensive understanding of how human well-being might be impacted by climate change. It is not clear, yet, how migration movements will evolve under future climate change scenarios.

Lonergan (1998) and Black (2001) have argued that the decision to migrate is always context dependent and locationally specific. Research needs to be historical in nature, and to appreciate the rich contextual and contingent nature of these complex relationships and decisions. Only from such a vantage point can we can appreciate the reasons why structures look the way that they do, and thus begin to think about why people will move, what the impacts of that movement might be and what measures might be taken to best secure human well-being. For in all of the politics about environment and migration, this, surely, must be a goal about which everyone is in agreement.

\section{References}

Adger, N., T. Benjaminsen, K. Brown and H. Svarstad. 2001. Advancing a political ecology of global environmental discourses. Development and Change 32(4): 681-715.

Bakewell, O. 2008. Keeping them in their place: the ambivalent relationship between development and migration in Africa. Third World Quarterly 29(7): 1341-1358.

Barnett, J. and N. Adger. 2007. Climate change, human security and violent conflict. Political Geography 26: 639-655.

Bates, D. 2002. Environmental refugees? Classifying human migrations caused by environmental change. Population and Environment 23(5): 465-477.

Bilsborrow, R. 1992. Rural poverty, migration, and the environment in developing countries: three case studies. Background paper for World Development Report. Washington: The World Bank.

Black, R. 2001. Environmental refugees: myth or reality? Working Paper no. 34. Geneva: United Nations High Commissioner for Refugees.

Bohra-Mishra, P. and D. Massey. 2011. Environmental degradation and out-migration: evidence from Nepal. In E. Piguet, A. Pécoud and P. De Guchteneire (eds.) Migration and climate change. Cambridge: Cambridge University Press. Pp74-101.

Bosswick, W. 2000. Development of asylum policy in Germany. Journal of Refugee Studies 13(1): 43-60.

Campbell, K. 2008. Climatic cataclysm: the foreign policy and national security implications of climate change. Washington DC: Brookings Institution Press.

Castles, S. 2002. Environmental change and forced migration: making sense of the debate. New Issues in Refugee Research, Working Paper no. 70. Oxford: Refugee Studies Centre, University of Oxford. http://tinyurl.com/cjrr4cy

Castles, S. and M. Miller. 2009. The age of migration: international population movements in the modern world. New York: Palgrave Macmillan.

Christian Aid 2007. Human tide: the real migration crisis. London: Christian Aid.

Conisbee, M. and Simms, A. 2003. Environmental refugees: the case for recognition. London: New Economics Foundation.

Cournil, C. 2011. The protection of 'environmental refugees' in international law. In E. Piguet, A. Pécoud and P. De Guchteneire (eds.) Migration and climate change. Cambridge: Cambridge University Press. Pp359387.

Döös, B. 1997. Can large scale environmental migrations be predicted? Global Environmental Change 7(1): 41-61.

EACH-FOR. 2009. Environmental Change and Forced Migration Scenarios (EACH-FOR).[accessed August 5 2011]. http://www.each-for.eu/index.php?module=main

EACH-FOR. 2008. Preliminary findings from the EACH-FOR project on Environmentally Induced Migration. Bonn: United Nations University. http://tinyurl.com/6sde5w4

El-Hinnawi, E. 1985. Environmental refugees. Nairobi: United Nations Environment Programme.

Feng, S., A. Krueger and M. Oppenheimer. 2010. Linkages among climate change, crop yields and MexicoUS cross-border migration, Proceedings of the National Academy of Sciences of the United States of America. 107(32): 14257-14262.

Findlay, A. and A. Geddes. 2011. Critical view on the relationship between climate change and migration: Some insights from the experience of Bangladesh. In E. Piguet, A. Pécoud and P. De Guchteneire (eds.) Migration and climate change. Cambridge: Cambridge University Press. Pp 138-159.

Forsyth, T. 2003. Critical political ecology: the politics of environmental science. London: Routledge. 
Geddes, A. 2003. The politics of migration and immigration in Europe. London: Sage Publications.

Gemmene, F. 2011. How they became the human face of climate change. Research and policy interactions in the birth of the 'environmental migration' concept, In E. Piguet, A. Pécoud and P. De Guchteneire (eds.) Migration and climate change. Cambridge: Cambridge University Press. Pp 225-259.

Gibney, M. 2004. The ethics and politics of asylum: Liberal democracy and the response to refugees. Cambridge: Cambridge University Press.

Gill, N. 2010. 'Environmental refugees': Key debates and the contributions of geographers. Geography Compass. 4(7): 861-871.

Gleditsch, N., R. Nordås and I. Salehyan. 2007. Climate change and conflict: the migration link. Coping With Crisis Working Paper Series. New York: International Peace Academy. http://tinyurl.com/788q7b3

Goffman, E. 2006. Environmental refugees: how many, how bad? CSA Discovery Guides, ProQuest.

Hartmann, B. 2010. Rethinking climate refugees and climate conflict: Rhetoric, reality and the politics of policy discourse. Journal of International Development 22(2): 233-246.

Hugo, G. 1996. Environmental concerns and international migration. International Migration Review 30(1): 105-131.

IPCC. 1990. Policymakers' summary of the potential impacts of climate change. Canberra: Commonwealth of Australia.

Islam, M. 1992. Natural calamities and environmental refugees in Bangladesh, Refuge: Canada's periodical on refugees 12(1): 5-10.

Jacobson, J. 1988. Environmental refugees: a yardstick of habitability. Washington DC: World Watch Institute.

Joppke, C. 1999. Immigration and the nation-state: the United States, Germany, and Great Britain. Oxford: Oxford University Press.

Laczko, F. 2009. Migration, environment and climate change: Assessing the evidence. The German Marshal Fund of the United States.

Lonergan, S. 1998. The role of environmental degradation in population displacement. Environmental Change and Security Project Report. Vol. 4.

Massey, D., J. Arango, G. Hugo, A. Kouaouci, A. Pellegrino and E. Taylor. 1993. Theories of international migration: A review and appraisal. Population and Development Review 19: 431-466.

Massey, D., W. Axinn and D. Ghimire. 2007. Environmental change and out-migration: evidence from Nepal. Population Studies Center, Michigan: Institute for Social Research, University of Michigan.

Massey, D. 1990. Social structure, household strategies, and the cumulative causation of migration, Population index 56(1): 3-26.

McGregor, J. 1994. Climate change and involuntary migration: Implications for food security. Food Policy 19(2): 120-132.

McNamara, K. 2007. Conceptualizing discourses on environmental refugees at the United Nations, Population and Environment 29: 2-24.

McNamara, K. 2008. Pragmatic discourses and alternative resistance: Responses to climate change in the Pacific, Graduate Journal of Asia-Pacific Studies 6(2): 33-54.

McNamara, K. and C. Gibson. 2009. 'We do not want to leave our land': Pacific ambassadors at the United Nations resist the category of 'climate refugees'. Geoforum 40(3): 475-483.

Morrissey, J. 2009. Environmental change and forced migration. Workshop on Environmental Change and Forced Migration, January $8^{\text {th }} \& 9^{\text {th }}$. Oxford: Refugee Studies Centre, University of Oxford.

Mortreux, C. and J. Barnett. 2008. Climate change, migration and adaptation in Funafuti, Tuvalu. Global Environmental Change 19(1): 105-112.

Myers, N. 1993. Environmental refugees in a globally warmed world. BioScience 43(11): 752-761.

Myers, N. 1997. Environmental Refugees. Population and Environment 19(2): 167-182.

Myers, N. 2001. Environmental refugees: a growing phenomenon of the 21st century. Philosophical Transactions of the Royal Society: Biological Sciences. 357: 609-613.

Myers, N. 2005. Environmental refugees an emergent security issue. 13th Economic Forum, 23-27 May. Prague.

Myers, N. 2008. Personal Communication, Oxford. Interview conducted on the $14^{\text {th }}$ of April.

Myers, N. and J. Kent. 1995. Environmental exodus: An emergent crisis in the global arena. Washington DC: The Climate Institute.

O'Lear, S. 1997. Migration and the environment: a review of recent literature. Social Science Quarterly 78(2): 606-618.

Otunnu, O. 1992. Environmental refugees in sub-Saharan Africa: causes and effects. Refuge: Canada's periodical on refugees 12(1):11-14. 
Panda, A. 2010. Climate refugees: Implications for India, Economic and Political Weekly XLV(20): 76-79.

Perch-Nielsen, S., M. Bättig and D. Imboden. 2008. Exploring the link between climate change and migration, Climatic Change 91(3): 375-393.

Rajan, S. 2008. Blue alert: Climate migrants in South Asia. India: Greenpeace.

Raleigh, C., L. Jordan and I. Salehyan. 2008. Assessing the impact of climate change on migration and conflict. Social Development Department of the World Bank Group. http://tinyurl.com/7n8vu2y

Ramlogan, R. 1996. Environmental refugees: a review. Environmental Conservation 23: 81-88.

Reuveny, R. 2007. Climate change-induced migration and violent conflict. Political Geography 26: 656-673.

Reuveny, R. 2008. Ecomigration and violent conflict: Case studies and public policy implications. Human Ecology 36(1): 1-13.

Robbins, P. 2004. Political ecology: a critical introduction. Oxford: Blackwell.

Salehyan, I. 2008. From climate change to conflict? No consensus yet. Journal of Peace Research 45(3): 315326.

Saunders, P. 2000. Environmental refugees: the origins of a construct. In P. Stott and S. Sullivan. (eds.) Political Ecology: Science, Myth and Power. London: Arnold.

See, M. 2007. Draft protocol on environmental refugees: a report on the original meeting and the proposed amendments to the 1951 convention and 1967 protocol. Republic of the Maldives: Ministry of Environment, Energy and Water.

Smith, P. 2007. Climate change, mass migration and the military response. Philadelphia: Elsevier on behalf of the Foreign Policy Research Institute.

Stavropoulou, M. 2008. Drowned in definitions. Forced Migration Review 31: 11-12.

Suhrke, A. 1993. Pressure points: environmental degradation, migration and conflict. Workshop on Environmental Change, Population Displacement, and Acute Conflict, June 1991. Ottawa: Peace and Conflict Studies Program, University of Toronto and The American Academy of Arts and Sciences, Cambridge, MA.

Suhrke, A. 1994. Environmental degradation and population flows. Journal of International Affairs 47(2): 473-496.

Tacoli, C. 2009. Crisis or adaptation? Migration and climate change in a context of high mobility. Environment and Urbanization. 21(2): 513-525.

Tafesse, T. 2007. The migration, environment and conflict nexus in Ethiopia: a case study of migrant settlers in East Wollega Zone. Addis Ababa: Organisation for Social Science Research in Eastern and Southern Africa.

Trolldalen, J., N. Birkeland, J. Borgen, P. Scott, and G. Coles. 1992. Environmental refugees: a discussion paper. Norway: World Foundation for Environment \& Development (WFED) in cooperation with The Norwegian Refugee Council.

Warner, K. 2009. Migration: climate adaptation or failure to adapt? Findings from a global comparative field study. IOP Conference Series: Earth and Environmental Science 6(56): 1755-1315.

Warner, K. 2009. Personal Communication, Oxford. Interview conducted on the $8^{\text {th }}$ January 2009.

Warner, K., T. Afifi, A. De Sheribin, S. Adamo and C.Ehrhart. 2011. Environmental change and forced migration scenarios: methods and findings from Nile Delta, Sahel and Mekong Delta. In E. Piguet, A. Pécoud and P. De Guchteneire (eds.) Migration and climate change. Cambridge: Cambridge University Press. Pp188-221.

Watson, R. and D. Albritton. 2001. Climate change 2001: synthesis report. Cambridge: Cambridge University Press.

Westing, A. 1994. Population, desertification, and migration. Environmental Conservation 21(2): 109-114.

Westing, A. 1992. Environmental refugees: a growing category of displaced persons. Environmental Conservation 19(3): 201-207.

Wigley, T. 2005. The Climate Change Commitment, Science 307(5716):1766-1769.

Young, J. 1990. Post environmentalism. London: Belhaven Press.

Zolberg, A., A. Shurke, and S. Aguayo. 1989. Escape from violence: conflict and the refugee crisis in the developing world. Oxford: Oxford University Press. 


\begin{abstract}
The debate over 'environmental refugees' is prominent in the literature on environmental change and human migration. Protagonists in the debate are 'maximilists' and 'minimalists' depending on their support for the concept. This article argues for the use of 'proponents' and 'critics' of the term. A nuanced critique of the 'proponent account' is offered, showing how the 'environmental refugee' is a particular representation of the relationship between environmental change and migration. There are conceptual problems in 'proponent' models, regarding both migration and development. These pertain to a sedentary bias and a reliance on pushpull, neo-classical models of both migration and the migrant. Some accounts are ahistorical and apolitical. The article advocates a research agenda that focuses on the interactions between environmental and nonenvironmental factors in mobility decisions, and that is historically relevant and contextually specific.
\end{abstract}

Keywords: environment, migration, environmental refugee, discourse, representation

\title{
Résumé
}

Le débat sur 'réfugiés environnementaux' occupe une place importante dans la littérature sur les changements environnementaux et les migrations humaines. Les protagonistes du débat sont des 'maximilists' et 'minimalistes' en fonction de leur soutien pour le concept. Cet article plaide en faveur de l'utilisation de 'promoteurs' (protagonists) et 'critiques' du terme. Une critique nuancée des 'promoteurs' est offert, montrant comment le terme 'réfugié environnemental' est une représentation particulière de la relation entre les changements environnementaux et les migrations. Il ya des problèmes conceptuels dans les modèles de promoteur, concernant à la fois la migration et le développement. Ces derniers se rapportent à un biais sédentaire et une dépendance à l'égard de modèles néo-classiques de la migration et le migrant (push-pull). Certains comptes sont anhistorique et apolitique. L'article préconise un programme de recherche qui se concentre sur les interactions entre les facteurs environnementaux et non environnementaux dans les décisions de mobilité, et qui est historiquement et contextuellement spécifique.

Mots-clés: environnement, de migration, réfugiés de l'environnement, discours, représentation

\section{Resumen:}

El debate en torno a los 'refugiados medioambientales' es prominente en la literatura sobre cambio climático y migración humana. Las opiniones en ese debate se dividen entre los 'maximalistas' y los 'minimalistas', dependiendo de su apoyo a este concepto. En este artículo se ofrece una crítica detallada de los defensores del concepto, mostrando cómo el 'refugiado medioambiental' es una representación particular de la relación entre cambio medioambiental y migración. En modelos favorables al concepto hay problemas conceptuales en relación tanto a migración como a desarrollo. Estos problemas conciernen a una tendencia hacia lo sedentario y a una confianza excesiva en modelos neoclásicos de empuje y atracción respecto tanto a la migración como al migrante. Algunas explicaciones son ahistóricas y apolíticas. El artículo defiende un plan de investigación centrado en las interacciones entre factores medioambientales y no medioambientales en las decisiones de desplazarse, así como históricamente relevante y contextualmente específico.

Palabras clave: medio ambiente, migración, refugiado medioambiental, discurso, representación. 